\title{
Development of the House Architectural Design in the Gaza Strip
}

\author{
By Ahmed S. Muhaisen*
}

The architectural design of house buildings in the Gaza Strip was developed considerably during the last century. It referred to various factors, which all contributed to create distinctive architectural styles of house buildings.This paper identifies three types of houses in the Gaza Strip classified as sandstone, mud and concrete houses, according to their construction materials. They represent three different styles of house buildings that prevailed in the last decades. The paper highlights the impact of the available building materials on the development of the house architectural design in the Gaza strip, which evolved from the primitive mud house to the new high rise concrete buildings. It analytically describes the distinctive architectural elements and identifies the advantages and disadvantages of each of them. The study finally suggests some recommendations, most notably the need to preserve the traditional house buildings because of their historic and cultural values and to benefit from their various advantages in creating a local architectural style using modern building materials and techniques.

\section{Introduction}

Throughout history house buildings were developed from a simple form of construction used for shelter from environmental conditions to well-established houses with all means of comfort. ${ }^{1}$ This was a response of the growing desire of mankind for better life conditions. At any particular period of time, a house building form was significantly affected by various factors most notably, available building materials and the experiential understanding of climate and site. Halıcıoğlu (2012) mentioned that a traditional house is the result of the combined effects of climate conditions, building materials, construction techniques and socioeconomic conditions of any region. ${ }^{2}$ It is evident that there was rapid development of building materials and construction techniques, following the industrial revolution, in the middle of the 19th century. This led to a dramatical shift in building design and construction systems, from the traditional bearing walls to a skeleton system with an enclosing skin $^{3}$.

\footnotetext{
* Associate Professor, Islamic University of Gaza, Palestine.

1. Bernard Rudofasky, Architecture without Architect (New York: Museum of Modern Art, 1964).

2. Fahriye Halicioglu, "Analysis of Vernacular Architecture in Terms of Sustainable Considerations: The Case Of Şirince Village in Western Turkey," Alam Cipta 5, no. 2 (2012).

3. John Straube, "Historical Development of the Building Enclosure," Building Science Press. http://bit.ly/1HS5buM. [Accessed July 10, 2015.]
} 
Although the industrial revolution was experienced first in the western part of the word, its effects and results gradually spread all over the world in terms of building materials and technology. ${ }^{4}$

The architectural design of house buildings in the Gaza strip has changed dramatically during the last few decades, moving from the traditional courtyard type to the temporary style of concrete houses, which spread in most Arab and world countries. ${ }^{5}$ This change was the result of several factors, most notably the availability of construction materials, which affect the construction system and consequently the architectural design of the house. The different building materials that were available in the successive periods in Gaza seem to have had a major influence in bringing about qualitative shifts in the creation and design of buildings in general, and houses in particular. The building materials, considered in this paper include sandstone, which was commonly used during long periods of time extending for thousands of years, as can be seen through the various historic and monumental buildings still remaining in the Gaza strip. ${ }^{6}$ In addition to mud, which was used extensively in the houses of farmers and poor people, in the time when sandstone was used by rich people. ${ }^{7}$ Finally, with the entry of cement material to the Gaza strip in the first half of the last century, concrete houses emerged and spread widely leading gradually to the suspension of using sandstone and mud in construction. It should be noted, that the economic factors associated with the specifications of concrete houses, contributed significantly to the widespread of such types of buildings. However, this seems to have resulted in a relatively new architectural style that lacks relation to local architectural features and traditions of the community.

This paper aims to study the development of the house design in the Gaza Strip, with relation to available construction materials and techniques. For this purpose, it identifies three basic models of house buildings representing the main distinctive methods of house design and construction in Gaza during the last decades. The house models were classified as sandstone houses, mud houses, and concrete houses, according to the building materials. The paper describes the most prominent architectural features of each type and analyses an example, as a case study, that represents each of them. The study highlights the advantages and benefits of the considered models and, finally suggests the employment of the architectural features of local traditional houses in modern buildings.

4. David S. Landes, The Unbound Prometheus: Technological Change and Industrial Development in Western Europe from 1750 to the Present, $2^{\text {nd }}$ edition (New York: Press Syndicate of the University of Cambridge, 2003).

5. Eman Ismail, "Evaluation and Development Study of Housing Types Used in The Gaza Strip to Rebuild the Place Identity," pres. in The $4^{\text {th }}$ International Engineering Conference-Towards Engineering of $21^{\text {st }}$ Century (Palestine: Islamic University of Gaza, 2012).

6. Ahmed Muhaisen, "Restoration Works to Preserve the Historic Houses in the Old City of Gaza," pres. in The $1^{\text {st }}$ Conference on the Palestinian Heritage (Paris: Ecole normale supérieure, 15-16 March 2012).

7. Nihad Almughani, Architectural Heritage in Gaza (Ramallah: Rewaq, 2007). 


\section{About the Gaza Strip}

The Gaza Strip is located in the south-western part of Palestine; it extends on the Mediterranean coast with a length of about $45 \mathrm{~km}$ and a width that ranges between $6-12 \mathrm{~km}$, with an area of about $360 \mathrm{sq} . \mathrm{km}$ (Figure 1). ${ }^{8}$ There are about 1.79 millions of people living in the Gaza strip, spread over the five major cities and eight refugee camps ${ }^{9}$. Gaza is the largest city, with an area of about $45 \mathrm{sq}$. $\mathrm{km}$ and a population of about 0.7 million people.

Figure 1. Location of the Gaza Strip

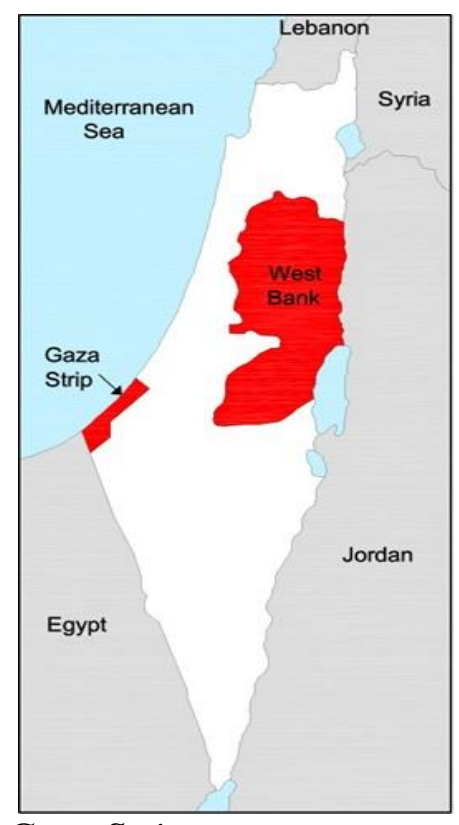

Source: Muhaisen, 2012. ${ }^{10}$

Gaza is one of the most ancient cities built by the Canaanites in about 3000 B.C. Many kingdoms and civilizations were sequenced on Gaza, such as Pharaohs, Greeks, Romanians, and finally the Islamic civilization, which began with the Islamic conquest at the hands of Amr Ibn Al-Aas during the reign of Caliph Omar ibn Al-Khattab and ended at the end of the Ottoman Empire in 1917. ${ }^{11}$

The Gaza Strip is one of the most densely populated areas in the world. Its population density is about 5,000 people/sq. $\mathrm{km}$. The need for housing in the

8. Khalid F. Ubeid and Alhasan S. Albatta, "Sand Dunes of the Gaza Strip (Southwestern Palestine): Morphology, Textural Characteristics and Associated Environmental Impacts," Earth Sciences Research Journal 18, no. 2 (2014): 131-142.

9. Palestinian Central Peru of Statistics (PCPS), Population Statistics in the Gaza strip, http://bit.ly/1HS6aeB. [Accessed July 10, 2015.] Gaza.”

10. Muhaisen, "Restoration Works to Preserve the Historic Houses in the Old City of 1995).

11. Salim Almubaied, Gaza and its Strip (Cairo: Egyptian General Book Authority, 
Gaza strip increases on an on-going basis as a result of the natural population increase, which is about $3.41 \%$ per year. ${ }^{12}$

\section{The Need for Housing}

In ancient times, human sought shelter to protect himself from danger and to find some tranquility and comfort. He was motivated by his instinct to defend himself from predators and the fluctuating environmental conditions. ${ }^{13}$ Therefore, he resorted in the beginning to caves and caverns, and then began to benefit from his accumulated experience and knowledge of the surrounding environment to create some primitive houses, which gradually evolved with the development of his knowledge, and the increase in his need for housing. ${ }^{14}$ Primitive houses were influenced by several key factors: First, the climate, which has had a significant impact on the form of the buildings, and the protection methods from the prevailing climatic conditions of heat, cold or rain. ${ }^{15}$ Second the social conditions, including customs, traditions, religion, and culture, which influenced the nature of the relationship between the family members and society in general. This was reflected on the form of buildings and human settlements, which were developed to respond to such conditions. The third factor is the available building materials, which state the construction techniques, and thus the form of buildings and architectural design. ${ }^{16}$ For example, mud architecture is usually spread in areas where mud is available in abundance, whereas, wood or sandstone is used in other areas for construction where these materials are usually available.

However, the human vision about shelter has changed over the time, with the evolution of different aspects of life, which imposed a specific pattern of human behavior. ${ }^{17}$ Accordingly, a house is no longer seen by people as just a shelter to meet the basic and innate needs, but also as a place of rest and tranquility that has to include all possible means of comfort and luxury, which were not previously part of the requirements in the primitive form of shelter.

12. Palestinian Central Peru of Statistics (PCPS), Population Statistics in the Gaza strip.

13. Seyyedeh Majdzadeh and Siavash Sharifabad, "Formulation of Vernacular-Oriented Model in the City of Kerman," Journal of Scientific Research and Development 2, no. 4 (2015): 45-53.

14. Rudofasky, Architecture without Architect.

15. Nazife Ozay, "Comparative Study of Climatically Responsive House Design at Various Periods of Northern Cyprus Architecture," Building and Environment 40 (2005): 841852.

16. Kağan Günçe, Zafer Ertürk and Sevinç Ertürk, "Questioning the "Prototype Dwellings" in the Framework of Cyprus Traditional Architecture," Building and Environment 43 (2008): 823-833.

17. Pindo Tutuko and Zhenjiang Shen, "Vernacular Pattern of House Development for Home Based Enterprises in Malang Indonesia," International Review for Spatial Planning and Sustainable Development 2, no. 3 (2014): 63-77. 


\section{House Types in the Gaza Strip}

This paper identified three types of houses in the Gaza Strip that formed qualitative transformations in the design of residential buildings during the last century and the beginning of the present one. They were classified according to the clear difference in their architectural design, which was a direct result of the different construction materials. Each type has distinguished features, grouped together to form a specific style that characterizes each of them. The sections below provide more details about the architectural features of the selected types:

\section{Sandstone House}

Sandstone material was used over very long periods of time in Gaza. It was considered the basic building material for permanent buildings and houses of rich people, who could afford it. It used to be mined from ancient quarries located to the east and north directions of the old city of Gaza. ${ }^{18}$ Currently, the quarries are almost no longer available, as they were covered by the expansion of the city built up areas, especially after the stop of using such material in buildings in the middle of the last century. In Gaza City there are many traditional houses built of sandstone which still preserve their distinctive architectural design and elements. The number of such houses is about 130 houses, distributed on the three neighborhoods of the old City of Gaza, namely, Daraj, Zaitoon and Shijaia. ${ }^{19}$ The majority of houses date back to the Ottoman era, which continued in the Gaza Strip in the period 1517-1914. ${ }^{20}$

The architectural design of traditional sandstone houses is characterized by many features, which could be identified depending on a field visit by the researcher to most of the remaining houses in Gaza. The characteristics of sandstone houses can be summarized as follows:

\section{Characteristics of Sandstone House}

The courtyard is considered the most important feature of traditional houses in Gaza city, as the majority of the remaining houses have a small courtyard surrounded by habitable rooms (Figures 2 and 3). It represents the lively heart of the house, since most of the social and daily activities of the inhabitants are carried out in it. It is a meeting place for all family members, and a place to receive guests from neighbors and friends, especially women. It also has an advantageous environmental role in modifying the climatic conditions and achieving thermal comfort. The courtyard provides internal shade during the summer and access to warm sunshine during the winter. Also

18. Almughani, Architectural Heritage in Gaza.

19. Ministry of Tourism and Antiquities, National Register of Heritage (Gaza, 2015).

20. Aref Alaref, History of Gaza (Jerusalem: Islamic Orphanage Press, 2006). 
it provides daylight to the surrounding living spaces. ${ }^{21}$ Planting the courtyard with some trees and vegetation also contributes to the achievement of comfortable thermal conditions, through the effect of vegetation in the humidification of air and reducing its temperature in the courtyard space.

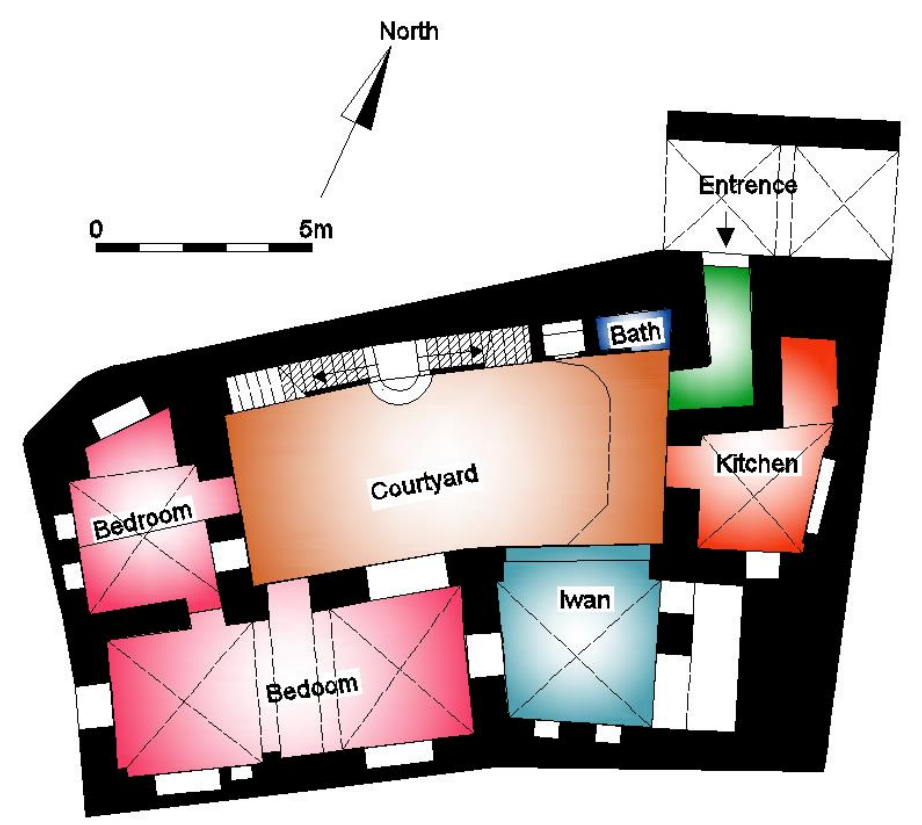

Figure 2. Plan of a Courtyard Sandstone House in Gaza (Alamy House) Source: Reproduced, Muhaisen, 2012. ${ }^{22}$

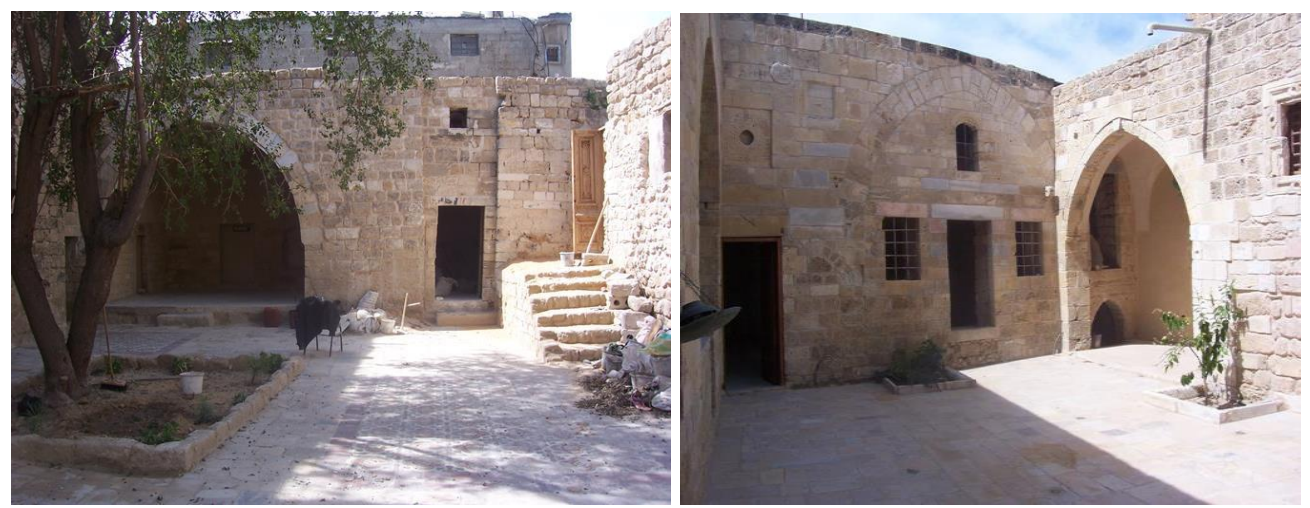

Figure 3. (Left) \& (Right) Courtyard Spaces in Sandstone Houses in Gaza Source: Author, 2015.

Iwan also represents a distinctive architectural element in sandstone houses. It is an internal space surrounded by walls on three sides and it is open from the fourth one to the courtyard (Figure 4). It is usually used as a sitting room and is considered the enclosed living space that integrates with the open

21. Ahmed Muhaisen, "Shading simulation of the Courtyard Form in Different Climatic Regions," Building and Environment 41, no. 12 (2006): 1731-1741.

22. Muhaisen, "Restoration Works to Preserve the Historic Houses in the Old City of Gaza." 
space of the courtyard. The house includes a number of small bedrooms that range from two to four depending on the house area and number of family members. In addition to two small spaces are allocated in the kitchen and bathroom, which are usually open directly onto the courtyard, and in some cases there is a room for guests near the main entrance.

There is often a main entrance on the wall overlooking the street, which is usually simple in shape. However, in some cases, it is emphasized by an articulated arch made of colorful lime stones (Figure 4). The entrance usually opens on a broken walkway that leads indirectly at the end to the courtyard. The broken entrance is used to provide privacy to the house residents, as it blocks the visual access of the entrants and passers of the street and thus prevents seeing the courtyard space when the door is open.
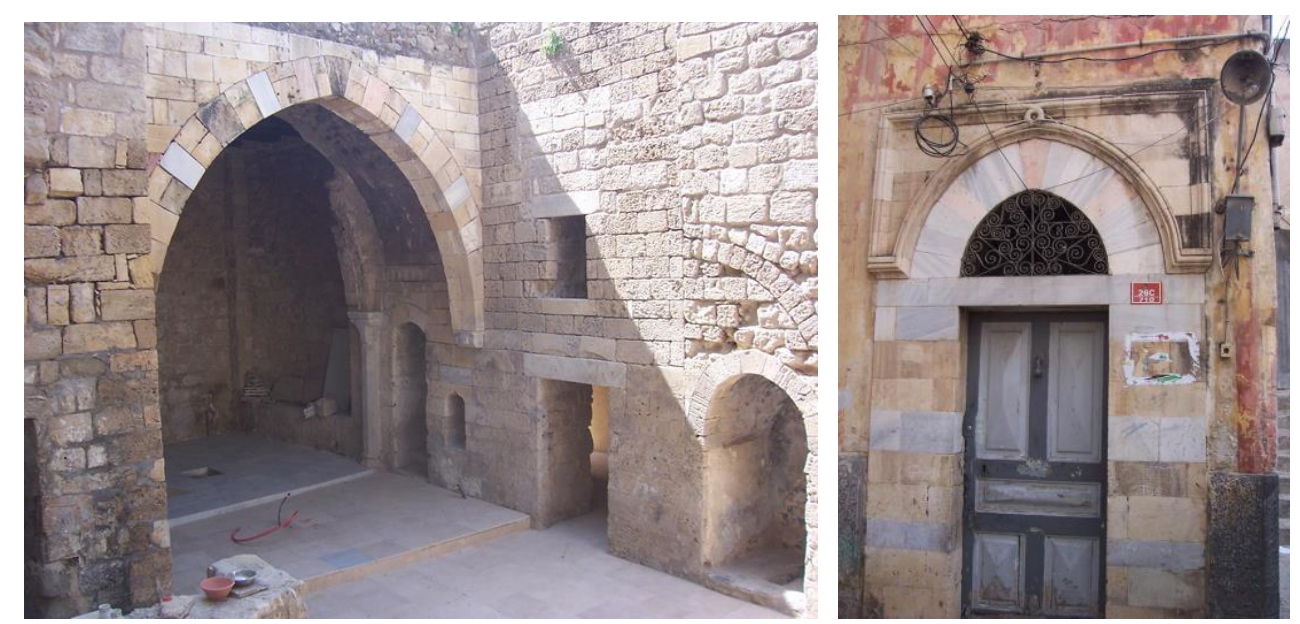

Figure 4. (Left) Iwan Space in a Sandstone House in Gaza; (Right) Articulated Entrance of a Sandstone House

Source: Author, 2013.

The external openings are few in number and small in area, in order toprovide privacy and to protect internal spaces from hot dusty winds during the summer. It usually relies on internal openings that overlook the courtyard to provide lighting and ventilation to the habitable rooms (Figure 5). In some houses, there are ornamented stone panels with geometric and organic units. They are used as decoration elements, especially on the walls overlooking the courtyard, to increase the esthetic value of the house, and to reflect the socioeconomic level of the occupants. 

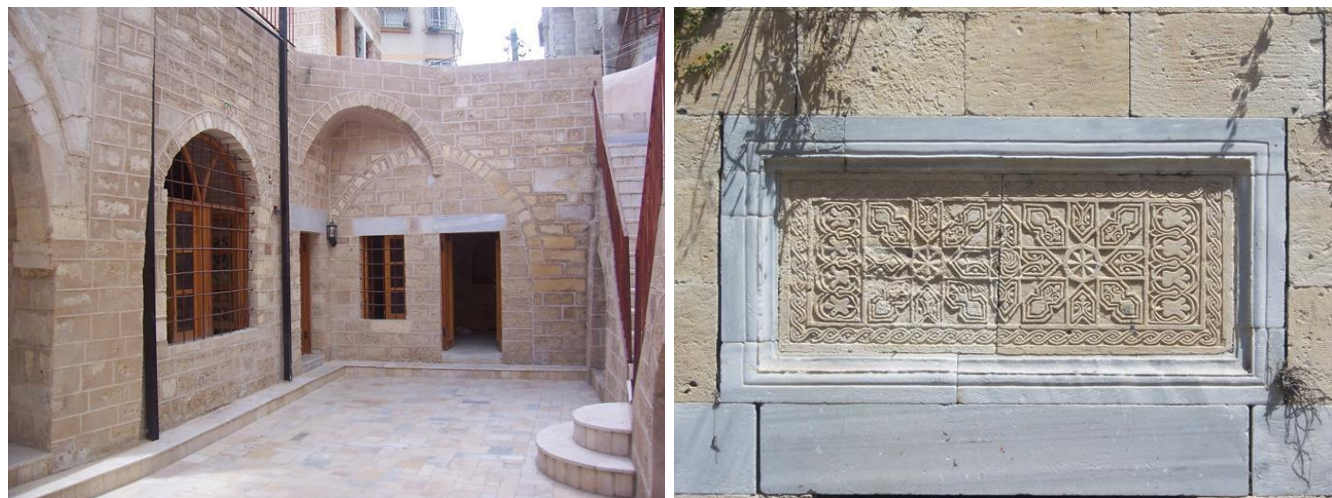

Figure 5. (Left) Room Windows Open onto the Courtyard; (Right) Ornamented Panels in a Sandstone House in Gaza

Source: Author, 2013.

The houses are built mainly of sandstones with a bearing wall structural system. The walls are thick enough to bear the dead and live loads, with some subtractions (niches) that are used as wall cabinets. The roofs are also made of sandstones, and take the form of intersecting vaults based directly on the walls, and look flat from the top level. The houses consist mainly of one floor, and in some cases, two floors maximum. They have usually uncovered staircases leadingto the upper floor, through the courtyard.

The following section presents a description of a traditional sandstone house taken as an example of such type of houses in Gaza city. It is the house of Deeb Ghalayini, which was visited more than once by the researcher to investigate its design and architectural elements.

\section{Deeb Ghalayini House}

It is Located in the old town of Gaza city, in the Zaitoon neighborhood, in Ghalayini alley, which is one of the oldest streets that still retain in Gaza. It was built during the Ottoman period, with an age of about 150 years old. The area of the house is about $230 \mathrm{~m}^{2}$, including an open courtyard with an area of $55 \mathrm{~m}^{2}$ surrounded by the living spaces of the house (Figures 6 and 7). It contains two bedrooms located in the eastern side, open directly on an arcade (Iwan) that separates them from the courtyard open space. The facade of the arcade overlooking the courtyard includes two pointed arches made of mutually colorful stones, and based on a Corinthian marble column (Figure 8). 


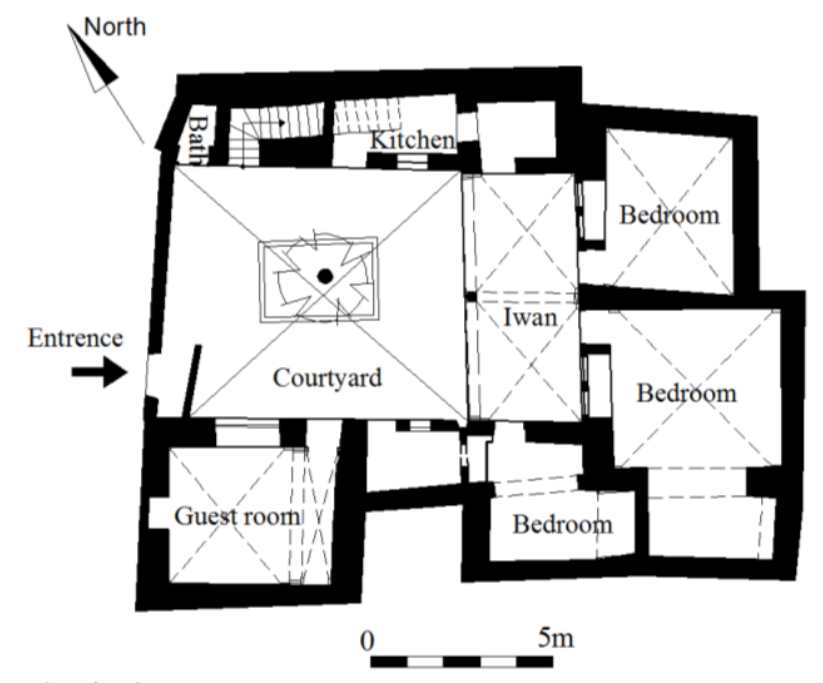

Figure 6. Plan of Ghalayini House in Gaza Source: Reproduced, IWAN Centre, 2012. ${ }^{23}$

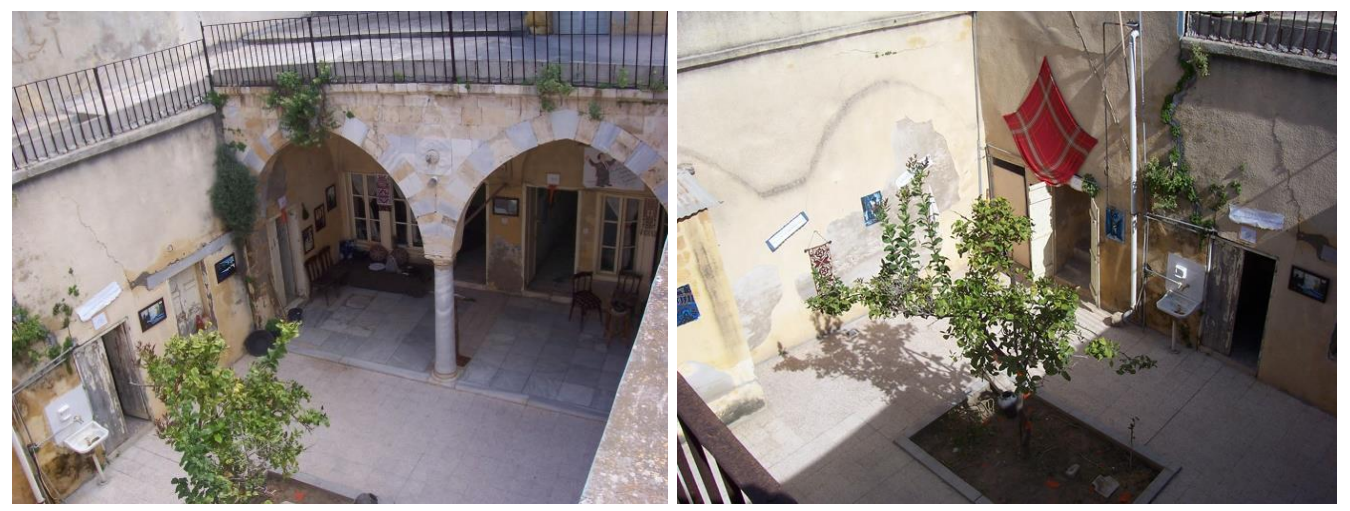

Figure 7. Courtyard Space of Ghalayini House in Gaza Source: Author, 2007.

In the southern side, there are also two rooms, the larger and closer to the entrance of the house is used usually for guests, while the other, which is smaller and irregularly shaped, is used for the family members. In the northern side there is a small kitchen and a bathroom in addition to the stairs that lead to the upper floor, which also includes a room and a bathroom that seem to be newly built. The main entrance of the house, in the western side, opens on a broken corridor to provide privacy for the residents, and then leads indirectly to the courtyard.

23. IWAN Center for Architecture Heritage, Achieve of Historical Buildings (Gaza, 2012). 

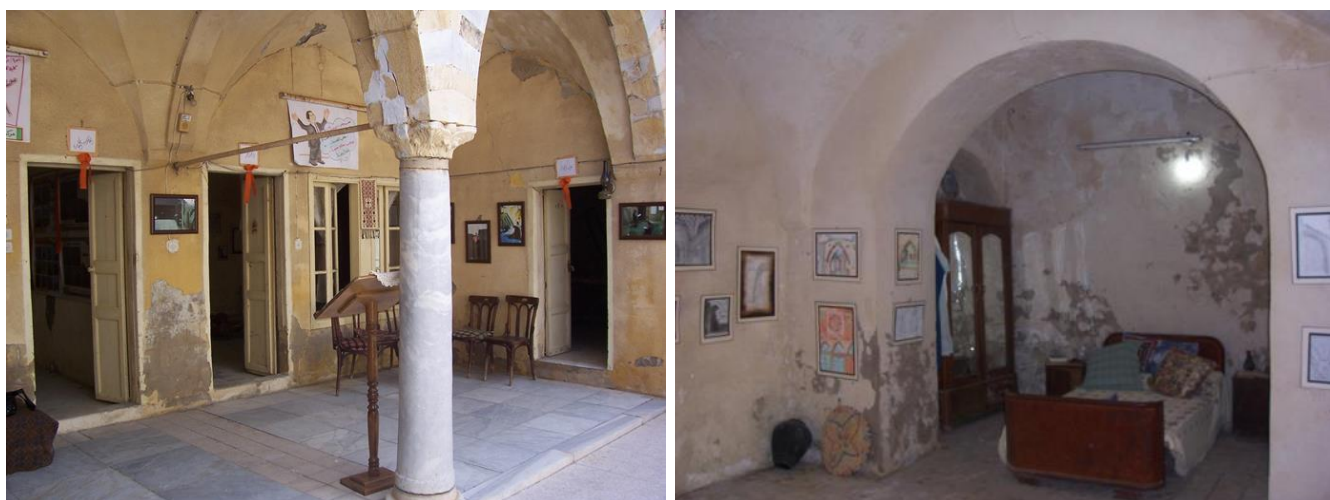

Figure 8: (Left) Iwan Space in Ghalayini House; (Right) Bedroom in Ghalayini House

Source: Author, 2007.

The house is built mainly of sandstone, in addition to some limestone material, which can be seen in the column and arches of the arcade, and the sills and lintels of some windows. There are no openings overlooking outside as a result of the attachment of the house to the adjacent buildings from three sides, while the fourth one, on the street, has no habitable rooms. The internal spaces rely on some windows in the courtyard to obtain natural lighting and ventilation. Thus, the courtyard is considered the most important space of the house, as in addition to its environmental role, most of the everyday household activities take place in it. In the middle of the courtyard there is a green land area where a lemon tree, which provides an aesthetical view, in addition to some shades and moisture that contribute to mitigate the hot air temperature inside the space, is planted.

\section{Mud House}

At the time when sandstone houses were used in the old city of Gaza, there was another model of mud houses commonplace outside the city in the remote and rural areas. Using mud was preferable to establish the houses of poor peasants and low-income people, because of its cheap costs compared with the sandstone buildings. This type of building is made mainly of clay, as a basic building material, to erect the walls and flat roofs, which were supported by branches of locally available trees at that time, such as palm, sycamore and eucalyptus trees. The advantageous characteristics of the mud construction method contributed significantly to the prevalence and spread of this type of building over a long period of time. This includes, as indicated by Dabaieh, (2011), the availability of clay material cheaply, simplicity to form and build, the possibility to build without the need for a highly skilled workforce, in addition to its advantages in providing comfortable thermal conditions during 
summer and winter due to the high thermal resistance of mud constructed walls and roofs. ${ }^{24}$

The construction of mud buildings were usually made collectively, where the owner, jointly with his neighbors and friends, work together to build his house in a unique social phenomenon that reflects the extent of cooperation prevailed in the construction of such buildings at that time (Figure 9). However, mud buildings had also disadvantages that locally hindered their development and continuity. This includes the lack of resistance to moisture and rainwater, which required a considerable maintenance on a regular basis, in addition to the limited ability to build multi-storey, buildings, or spaces with long spans. Currently, the majority of these buildings disappeared and they are no longer available due to the lack of maintenance and destruction processes of such buildings to build new ones, especially after the prevalence of using cement, as a new building material, which led to refrain from the use of mud in construction. However, due to the shortage of cement material currently entering the Gaza strip as a result of the siege imposed on the Gaza strip for many years, there have been some attempts to revive the method of using mud for construction. There are some successful cases reported in Gaza in the last few years for people who built their houses with mud, such as the case of Jihad Al Shaer, which was highlighted by Muhiasen (2010). ${ }^{25}$

\section{Features of Mud House}

The main feature of the mud houses was the existence of habitable spaces for residents, in addition to the other spaces designated for their animals and crops, Figure 9. The habitable rooms were generally small and open directly onto a small courtyard, whereas, the animal and crop rooms were relatively larger. As part of the courtyard, there was a place allocated for the mud oven, which was used for baking and cooking, in addition to another small space used as a bathroom. The roof of the large rooms was supported by stone arches based on stone pillars placed in the mud walls (Figure 10). These arches usually divide the internal space into sub divisions, and are locally called Kantara. $^{26}$ Generally, roofs of small rooms were flat based on the trunks and branches of trees such as palm and sycamore, and covered with mud from the top (Figure 11). Overall, domed or vaulted roofs were not commonly used, due perhaps to the difficulty to establish them, since such a type of roof requires skilled and well trained workers, and some techniques that were not generally available to the house owner who built his house himself with the help of neighbors. The openings were narrow and high at the top of the walls to provide privacy, and at the same time to obtain some natural ventilation and get rid of smells and excessive heat, especially in the summer nights.

24. Marwa Dabaieh, A Future for the Past of Desert Vernacular Architecture (Lund: Lund University Division of Architectural Conservation and Restoration, 2011).

25. Ahmed Muhaisen, "Study the Experience of Building with Mud in the Gaza Strip," Omron and Urban Techniques Journal August Issue, Mesilla University, 2011.

26. Almughani, Architectural Heritage in Gaza. 

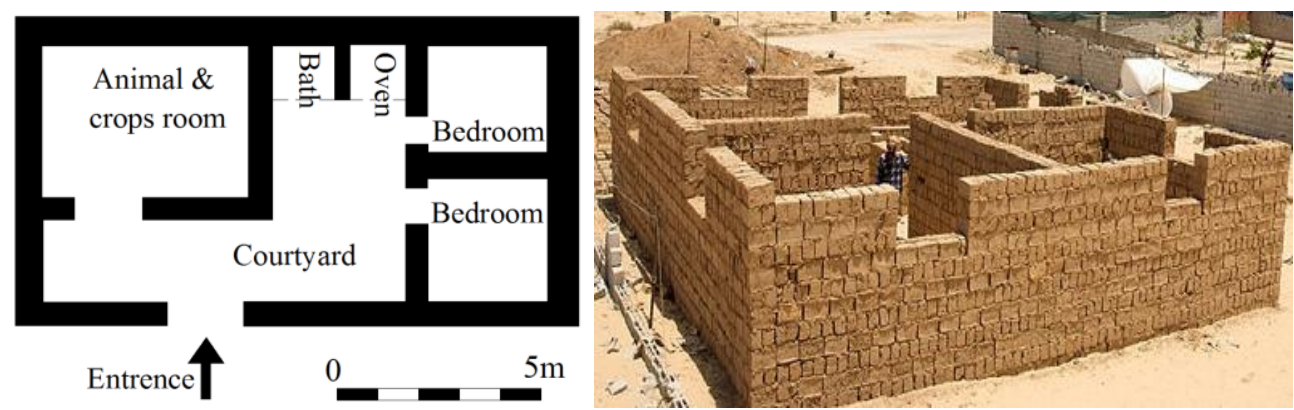

Figure 9. (Left) Plan of Traditional Mud House in Gaza

Source: Almughani, 2007. ${ }^{27}$

(Right) A Recent Mud House in Gaza in the Construction Process

Source: BBC, 2009. ${ }^{28}$
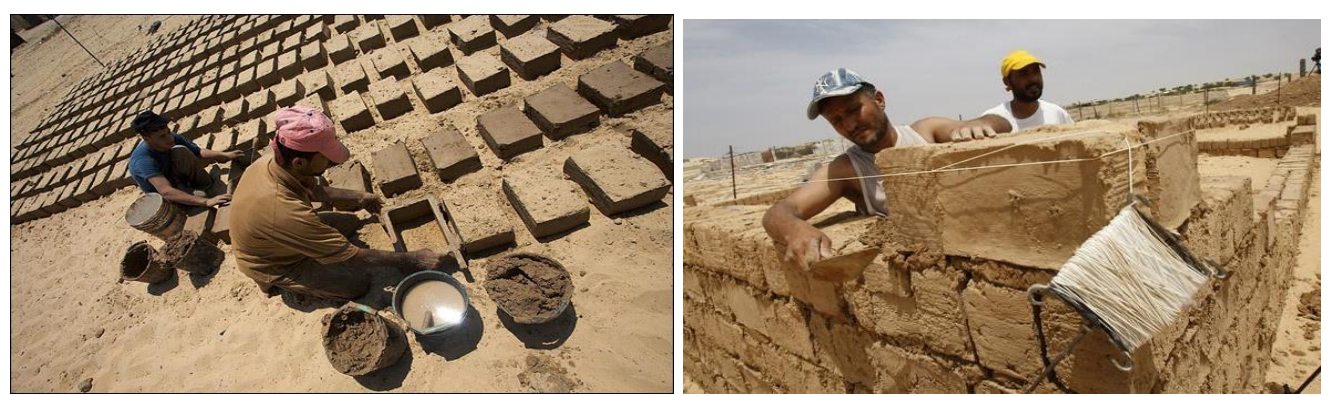

Figure 10. (Left) Preparing Mud Bricks in Gaza; (Right) Building Process of a Recent Mud House in Gaza

Source: BBC, 2009. ${ }^{29}$
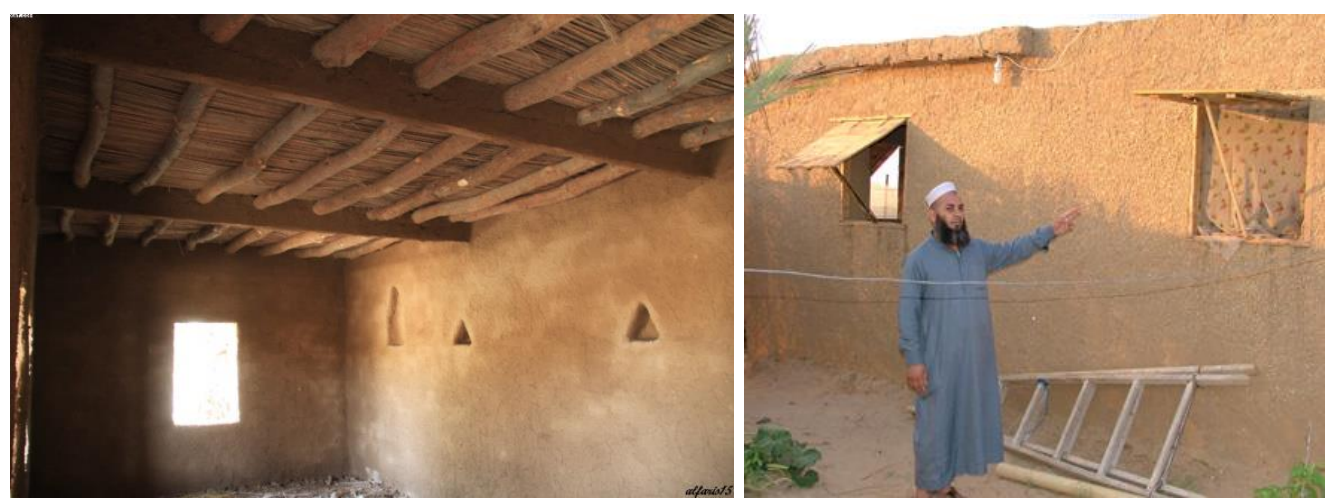

Figure 11. (Left) Roof of a Traditional Mud House

Source: Alfaris, 2015. ${ }^{30}$

(Right) A Complete Mud House, Recently Built in Gaza

Source: BBC, 2009. ${ }^{31}$

27. Almughani, Architectural Heritage in Gaza.

28. BBC Arabic, "Siege Revives Mud Houses in Gaza," http://bbc.in/1H5ZEkj.

[Accessed July 10, 2015.]

29. BBC Arabic, "Siege Revives Mud Houses in Gaza."

30. Khalid Alfaris, Building with Mud, http://bit.ly/1PLG0vi. [Accessed July 10, 2015.]

31. BBC Arabic, "Siege Revives Mud Houses in Gaza." 


\section{Concrete House}

With the entry of cement material to Gaza in the first half of the $20^{\text {th }}$ century, concrete houses, made mainly of concrete material, spread and became the most common way of construction (Figure 12). Concrete allowed the construction of multistory buildings, which reduces the land consumption, helped to speed up the construction process and consequently saved time and provided a high degree of flexibility in the design and use of spaces. ${ }^{32}$

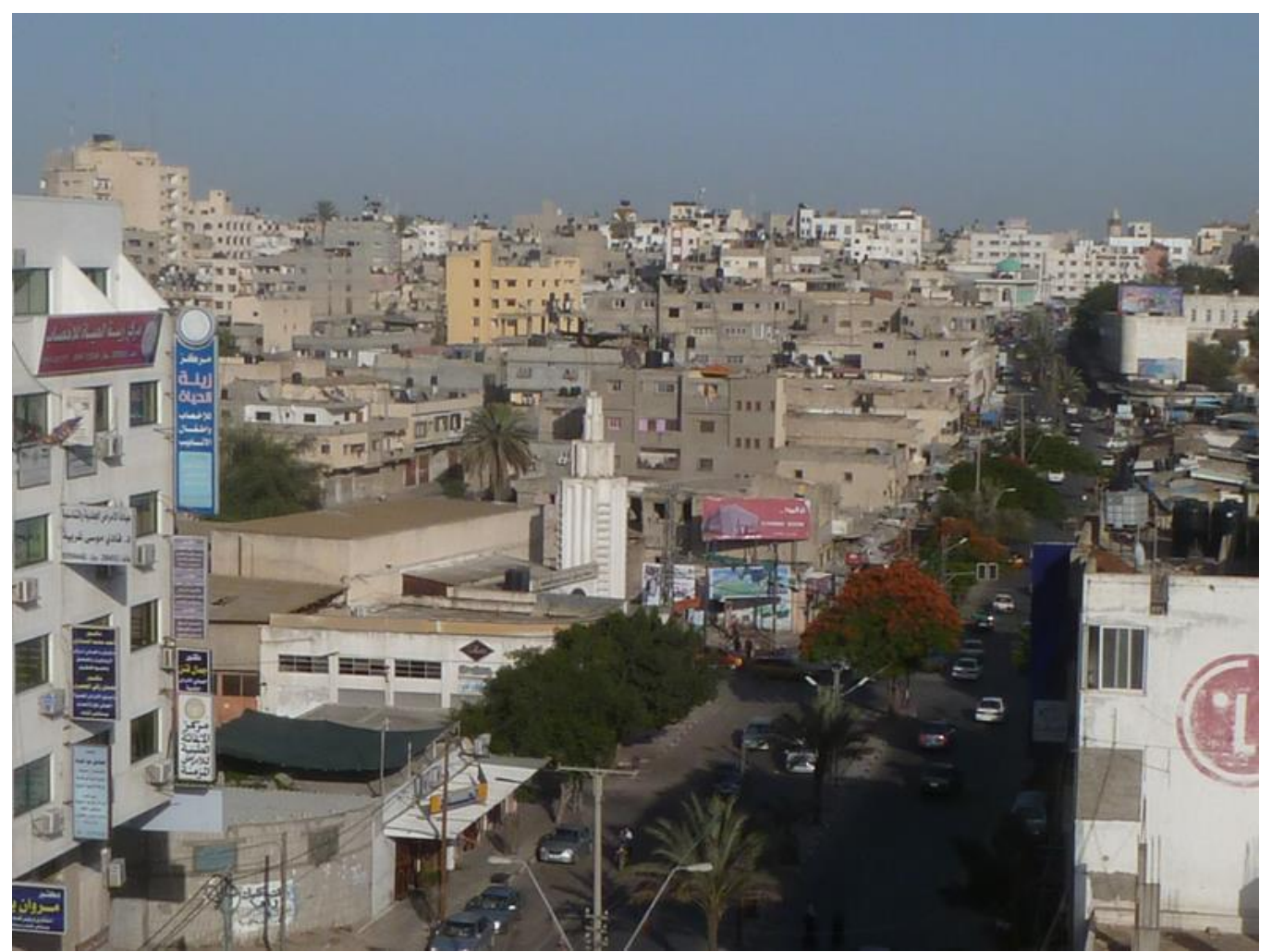

Figure 12. An Overview of Gaza City Showing the Concrete Buildings

Source: Author, 2014.

This led to a gradual declination in using sandstone and mud materials in construction, until it was stopped in the second half of the $20^{\text {th }}$ century. As a result of using concrete, the construction sector of buildings was generally developed, and accordingly the architectural design of residential units was significantly transformed. The most important variations in the design and construction of the residential buildings due to using concrete can be summarized as follows:

- Moving more towards multi-storey vertical buildings to respond to the growing need for housing, in a very limited area of land.

32. European Concrete Platform, Sustainable Benefits of Concrete Structures (Brussels: The European Concrete Platform, 2009). 
- Use of skeleton construction systems, which led to the external and interior walls as screens and partitions that can be freely designed.

- Use of light materials and a variety of exterior and interior finishing materials.

- Design of large external openings without affecting the construction system.

This development in the construction method of concrete buildings contributed to achieving the following:

- Speed up the construction process, which led to saving time.

- Increase of the population density as a result of vertical building design, which resulted in reducing the land consumption.

- Reduction of the construction costs of buildings.

- Increase of the possibility to use advanced technologies to achieve comfort inside buildings, such as air conditioners, electrical elevators and other equipment.

- Increase of flexibility in design and encourage innovative and distinctive architectural forms.

However, this development had some negative effects, which can be summarized as follows:

- The absence of a local character or identity in the concrete buildings, which have a global style that is spread in most countries of the world (Figure 13).

- Losing many of the traditional architectural elements in buildings, which are considered the most important symbols of the local architecture in Gaza, such as the courtyard, arches, domes, ornaments, Iwan and others.

- Increased reliance on modern technology to provide thermal and acoustical comfortable conditions, due to the low resistivity of concrete block walls compared to that of sandstone or mud.
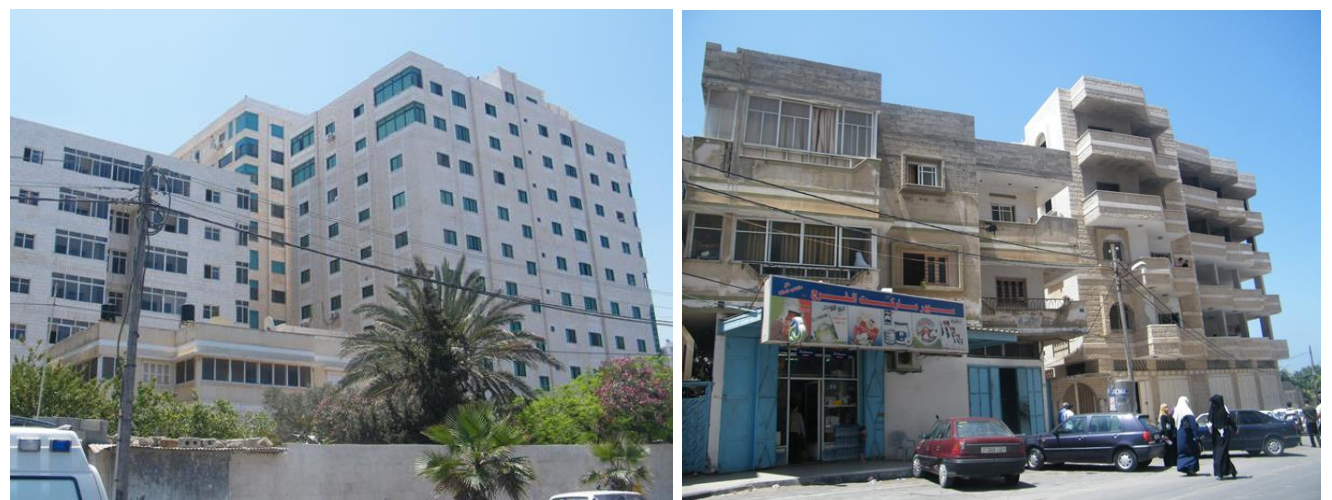

Figure 13. (Left) \& (Right) Global Style of Concrete House Buildings in Gaza Source: Author, 2015. 
The following is an analysis of a recent model of a concrete house in Gaza:

\section{Concrete House Examples}

Figures 14, 15 and 16 present examples of concrete multi-storey house buildings, which are commonly spread in the Gaza Strip. Each storey of the building consists usually of one, two or four flats, depending on the plot area of the building. The flat consists of three zones: sleeping, living, and service zones. The sleeping zone includes three adjacent bedrooms and a bathroom; located inward away from the main entrance. The living zone, consisting of the living and dining rooms, it is located in the middle of the unit to accommodate the common family activities. The zone of services that include the kitchen, guest room and WC is usually near the main entrance to preserve the privacy of the residents when guests enter the house. There are usually a number of balconies overlooking outside used for siting, especially during the summer, to expose to mild breezes, and enjoy the surrounding views, if any. The building is based on a skeleton structural system made of reinforced concrete, which distinguishes such type of buildings. The walls are made of plastered concrete hollow blocks, while windows are single glazed with aluminum farms. External openings are openable and medium in size, constituting about 10-15\% of the external wall areas.

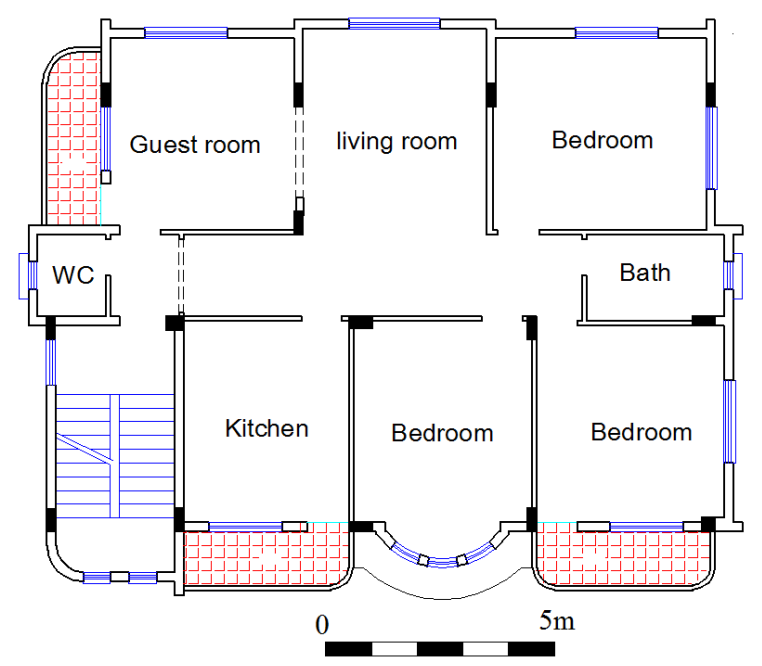

Figure 14. A Plan of a Single Flat Multi-storey Concrete Building in Gaza Source: Eliaa Office, 2015. ${ }^{33}$

33. Eliaa Office, Architectural Design of Concrete Houses in Gaza (Gaza, 2015). 


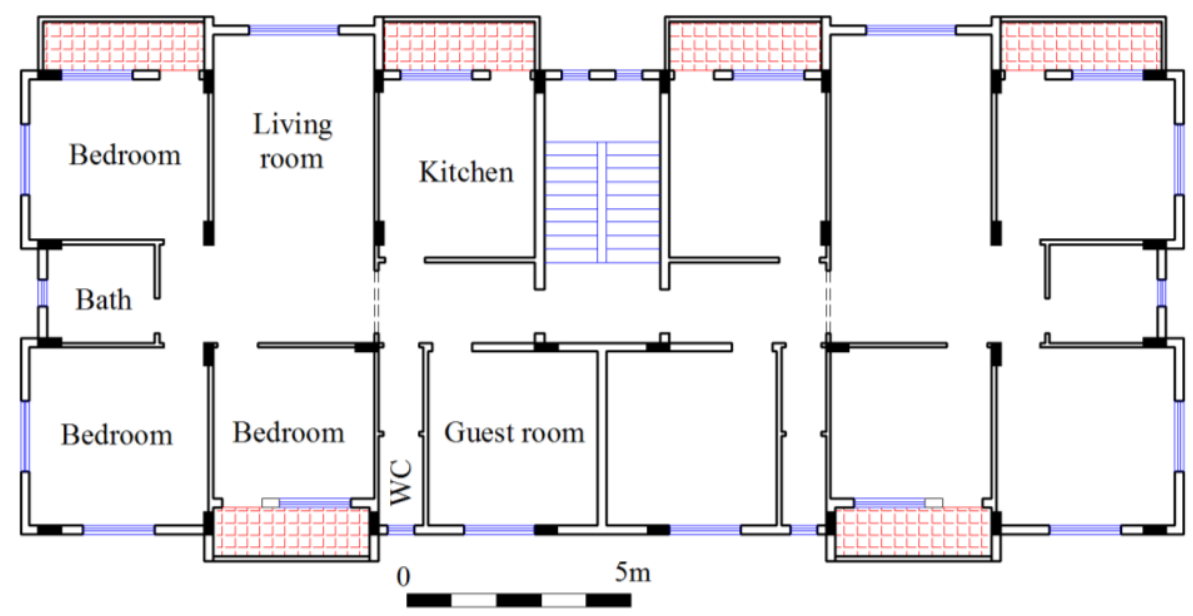

Figure 15. A Plan of a Two-flat multi-storey Concrete Building in Gaza Source: Eliaa Office, $2015 .^{34}$

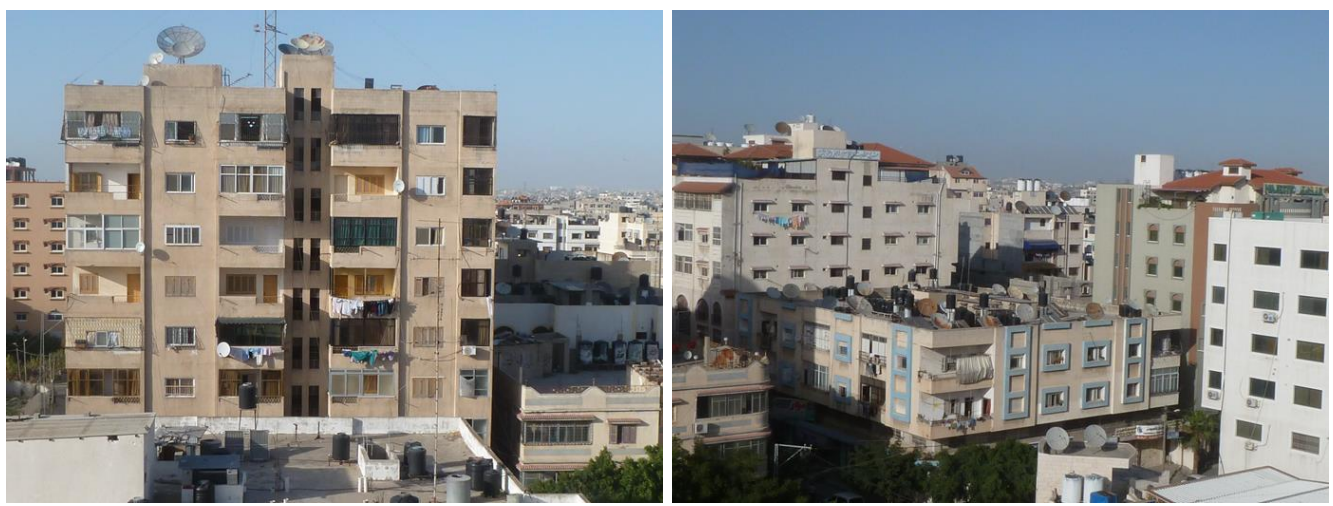

Figure 16. (Left) \& (Right) Multi-storey Concrete House Buildings in Gaza Source: Author, 2015.

\section{Comparison between the Three House Designs}

Based on the abovementioned description of the house types, it is noted that there is a clear difference between the architectural designs of past and present prototypes. It is evident that the construction materials have significantly affected the house development, along with other economic and social factors that cannot be ignored. The developed form of the recent concrete house has many positive factors, particularly with regard to the reduction of built up areas and providing more comfort to the inhabitants. However, it had also other negative impacts, related to the absence of architectural identity. To find out more about the pros and cons of each type of the examined house buildings, the following comparison between them was made based on several criteria, as shown in Table 1 .

34. Ibid. 
Table 1. Comparison between the House Types in the Gaza Strip

\begin{tabular}{|c|c|c|c|c|}
\hline No. & Criterion & $\begin{array}{l}\text { Sandstone } \\
\text { House }\end{array}$ & $\begin{array}{l}\text { Mud } \\
\text { House }\end{array}$ & $\begin{array}{l}\text { Concrete } \\
\text { House }\end{array}$ \\
\hline 1 & Design Flexibility. & $\mathbf{\Delta}$ & $\bullet$ & ma \\
\hline 2 & Maintains local architectural identity. & $\mathbf{m}$ & $\boldsymbol{\Delta}$ & $\bullet \bullet$ \\
\hline 3 & $\begin{array}{l}\text { Respects the customs and traditions of } \\
\text { the community. }\end{array}$ & $\mathbf{m}$ & $\boldsymbol{\Delta}$ & $\boldsymbol{\Delta}$ \\
\hline 4 & Provides privacy & m & $\bullet \bullet$ & $\boldsymbol{\Delta}$ \\
\hline 5 & Respects the human scale. & - & m & $\boldsymbol{\Delta}$ \\
\hline 6 & $\begin{array}{l}\text { Appropriates with the environmental } \\
\text { conditions. }\end{array}$ & m & घ & $\bullet \bullet$ \\
\hline 7 & Saves energy. & $\mathbf{m}$ & - & $\bullet \bullet$ \\
\hline 8 & Reduces land consumption. & $\bullet \bullet$ & $\bullet \bullet$ & m \\
\hline 9 & Possibility of vertical expansion. & $\boldsymbol{\Delta}$ & • & m \\
\hline 10 & $\begin{array}{l}\text { Provides thermal and acoustic } \\
\text { insulations. }\end{array}$ & - & घ & $\bullet \bullet$ \\
\hline 11 & $\begin{array}{l}\text { Makes use of new technologies to } \\
\text { provide comfort. }\end{array}$ & $\bullet \bullet$ & $\bullet$ & $\mathbf{\square}$ \\
\hline 12 & Sustainability. & $\boldsymbol{\theta}$ & घ & $\boldsymbol{\Delta}$ \\
\hline 13 & Availability of construction materials. & $\bullet \bullet$ & $\boldsymbol{\Delta}$ & m \\
\hline 14 & Reduces construction costs. & $\boldsymbol{\Delta}$ & II & - \\
\hline 15 & Reduces maintenance costs. & - & $\bullet \bullet$ & - \\
\hline 16 & Speed in construction. & $\bullet \bullet$ & - & $\boldsymbol{\Delta}$ \\
\hline 17 & Esthetic value of the building. & - & $\bullet \bullet$ & $\boldsymbol{\Delta}$ \\
\hline 18 & $\begin{array}{l}\text { Ability to have wide external } \\
\text { windows. }\end{array}$ & $\bullet \bullet$ & • & $\mathbf{m}$ \\
\hline 19 & Provides comfort and welfare. & $\boldsymbol{\Delta}$ & $\bullet \bullet$ & $\mathbf{\square}$ \\
\hline 20 & $\begin{array}{l}\text { Options of internal and external } \\
\text { finishing. }\end{array}$ & $\bullet \bullet$ & - & $\mathbf{m}$ \\
\hline \multicolumn{2}{|c|}{$\begin{array}{l}\text { Key of Symbols: • Very little } \bullet \bullet \text { Little } \\
\text { significant }\end{array}$} & $\Delta$ Medium & - Significant & - Very \\
\hline
\end{tabular}

It is observed that the concrete house option is the most preferable, with (Very significant) a rating scale, in 35\% of the standards, which is the highest percentage compared with the sandstone and clay houses, which are equally achieved $15 \%$ in this category. The sandstone house option is significant, in $35 \%$ of the standards, whereas, the other two options achieved equally $15 \%$. The clay house option is the intolerable (Very little) and undesirable (Little) option in $25 \%$ and $30 \%$ of the standards respectively. It is noticed that the concrete and sandstone options are never the worst (Very little) options in any of the standards.

Accordingly, the concrete house option seems to be the most preferable, followed by the sandstone house option, whereas, the clay house is the last in the scale of preferability. Table 2, summarizes the advantages and disadvantages of the concrete and sandstone options, depending on the comparison and previous descriptions of each of them. 
Table 2. Comparison between the Concrete and Sandstone House Options

\begin{tabular}{|c|c|c|}
\hline & Concrete house & Sandstone House \\
\hline Advantages & $\begin{array}{l}\text { - Flexible in design. } \\
\text { - Reduces built up areas of } \\
\text { land. } \\
\text { - The possibility to employ } \\
\text { new technologies to increase } \\
\text { internal comfort. } \\
\text { - Requires Low maintenance } \\
\text { costs. } \\
\text { - Design of windows is } \\
\text { unrestricted. } \\
\text { - Uses multiple options for } \\
\text { external and internal } \\
\text { finishings. } \\
\text { - The availability of } \\
\text { construction materials in } \\
\text { abundance. } \\
\text { - Expands in a vertical } \\
\text { manner easily. } \\
\text { - Saves time in construction. }\end{array}$ & $\begin{array}{l}\text { - Preserves local architectural } \\
\text { identity. } \\
\text { - Provides high degree of } \\
\text { privacy. } \\
\text { - Suitable for the customs and } \\
\text { traditions of the community. } \\
\text { - Responds to local climatic } \\
\text { conditions. } \\
\text {-Reduces energy } \\
\text { consumption. } \\
\text { - Respects the human scale. } \\
\text { - More sustainable. }\end{array}$ \\
\hline Disadvantages & $\begin{array}{l}\text { - The lack of local } \\
\text { architectural style. } \\
\text { - Low adaptability to local } \\
\text { climatic conditions. } \\
\text { - Insufficient thermal and } \\
\text { acoustic insulations. } \\
\text { - Considerable consumption } \\
\text { of energy. }\end{array}$ & $\begin{array}{l}\text { - Uses large areas of land. } \\
\text { - Inflexible in windows } \\
\text { design. } \\
\text { - Takes more time for } \\
\text { construction. } \\
\text { - Limited options of external } \\
\text { and internal finishings. } \\
\text { - The lack of construction } \\
\text { materials in abundance. }\end{array}$ \\
\hline
\end{tabular}

Although the concrete house is the best option in many of the standards, which encourages continuing to use it, the sandstone house has also some features that cannot be ignored, since many of them are considered weaknesses for the concrete house. Thus, it is wise to take full advantage of the traditional sandstone features and adapt them in accordance to the properties of concrete buildings. In this way, it will be possible to benefit from the features of both types, and contribute to pair between tradition and modernity in order to produce a local architectural style with modern construction materials and techniques. This does not necessarily mean the transfer of the conventional architectural elements as they are and the reproduction of them in the same way, without change. But it is meant to take full advantage of the positive features and characteristics of the traditional architecture in the design of modern buildings in an innovative way. 


\section{Conclusions}

It is evident that the building materials had a significant impact on the development of the design and construction methods of house buildings in the Gaza Strip during the last periods. This was made clear through the analysis of three types of common house buildings in Gaza, namely sandstone, clay and concrete house styles. Each of these types has some advantages that encouraged residents to use them during a specific period of time, in addition to some drawbacks that led probably to abandon it at a later period in favor of another more sophisticated type. This is apparent in the stop of using sandstone and clay houses, in favor of concrete house, which has become the most predominant type in the Gaza Strip, as a result of its many positive features compared with the others.

It is concluded that the architectural design of the house buildings in Gaza evolved from the traditional form, which includes an open courtyard surrounded by living spaces, and is built of local materials such as sandstone or mud, to the concrete house style, which relies on new techniques to provide comfort. The movement towards the concrete house style seems to be justified due to its many advantages, especially with regard to the cheap construction costs, the reduction of land use, and design flexibility. However, its negative impact on losing the traditional architectural identity is one of the most important drawbacks needed to be handled. In this context, the study recommends to take full advantage of the traditional architectural features in the design and construction of concrete houses and modern buildings. This is seen to be a step forward to creating a local architectural style that corresponds to the social and environmental conditions prevailing in Gaza, and at the same time be in line with the major developments in the field of building materials and techniques. This should not be, however, understood to be an invitation to blindly imitate, or refer to the back and abandon the development, but it is a call for integrating the features of traditional and modern designs of house buildings in an innovative way.

\section{Bibliography}

Alaref, Aref. History of Gaza. Jerusalem: Islamic Orphanage Press, 2006.

Alfaris, Khalid. Building with Mud. http://bit.ly/1PLG0vi. [Accessed July 10, 2015.]

Almubaied, Salim. Gaza and its Strip. Cairo: Egyptian General Book Authority, 1995. Almughani, Nihad. Architectural Heritage in Gaza. Ramallah: Rewaq, 2007.

BBC Arabic. "Siege Revives Mud Houses in Gaza." http://bbc.in/1H5ZEkj. [Accessed July 10, 2015.]

Dabaieh, Marwa. A Future for the Past of Desert Vernacular Architecture. Lund: Lund University Division of Architectural Conservation and Restoration, 2011.

Eliaa Office. Architectural Design of Concrete Houses in Gaza. Gaza, 2015.

European Concrete Platform. Sustainable Benefits of Concrete Structures. Brussels: The European Concrete Platform, 2009. 
Günçe, Kağan, Zafer Ertürk and Sevinç Ertürk. "Questioning the "Prototype Dwellings" in the Framework of Cyprus Traditional Architecture." Building and Environment 43 (2008): 823-833.

Halicioglu, Fahriye. "Analysis of Vernacular Architecture in Terms of Sustainable Considerations: The Case Of Şirince Village in Western Turkey." Alam Cipta 5, no. 2 (2012).

Ismail, Eman. "Evaluation and Development Study of Housing Types Used in The Gaza Strip to Rebuild the Place Identity." Presented in The $4^{\text {th }}$ International Engineering Conference-Towards Engineering of $21^{\text {st }}$ Century. Palestine: Islamic University of Gaza, 2012.

IWAN Center for Architecture Heritage. Achieve of Historical Buildings. Gaza, 2012.

Landes, David S. The Unbound Prometheus: Technological Change and Industrial Development in Western Europe from 1750 to the Present, $2^{\text {nd }}$ Edition. New York: Press Syndicate of the University of Cambridge, 2003.

Majdzadeh, Seyyedeh and Siavash Sharifabad. "Formulation of Vernacular-Oriented Model in the City of Kerman." Journal of Scientific Research and Development 2 , no. 4 (2015): 45-53.

Ministry of Tourism and Antiquities. National Register of Heritage. Gaza, 2015.

Muhaisen, Ahmed. "Shading simulation of the Courtyard Form in Different Climatic Regions." Building and Environment 41, no. 12 (2006): 1731-1741.

Muhaisen, Ahmed. "Study the Experience of Building with Mud in the Gaza Strip." Omron and Urban Techniques Journal August Issue, Mesilla University (2011).

Muhaisen, Ahmed. "Restoration Works to Preserve the Historic Houses in the Old City of Gaza." Presented in The $1^{\text {st }}$ Conference on the Palestinian Heritage. Paris: Ecole normale supérieure, 15-16 March 2012.

Ozay, Nazife. "Comparative Study of Climatically Responsive House Design at Various Periods of Northern Cyprus Architecture." Building and Environment 40 (2005): 841-852.

Palestinian Central Peru of Statistics (PCPS). Population Statistics in the Gaza strip. http://bit.ly/1HS6aeB. [Accessed July 10, 2015.]

Rudofasky, Bernard. Architecture without Architect. New York: Museum of Modern Art, 1964.

Straube, John. "Historical Development of the Building Enclosure." Building Science Press. http://bit.ly/1HS5buM. [Accessed July 10, 2015.]

Tutuko, Pindo and Zhenjiang Shen. "Vernacular Pattern of House Development for Home Based Enterprises in Malang Indonesia." International Review for Spatial Planning and Sustainable Development 2, no. 3 (2014): 63-77.

Ubeid, Khalid F. and Alhasan S. Albatta. "Sand Dunes of the Gaza Strip (Southwestern Palestine): Morphology, Textural Characteristics and Associated Environmental Impacts." Earth Sciences Research Journal 18, no. 2 (2014): 131142 . 